\title{
Perancangan Mesin ATM dan Ruangan ATM Berdasarkan Ilmu Ergonomi (Studi Kasus di ATM "Bank A" Setrasari, Bandung)
}

\author{
The Design of ATM Machine and ATM Room Based on Ergonomics \\ (Case Study on “Bank A"ATM Setrasari, Bandung)
}

\author{
Dewi Christina Syamsir, Elty Sarvia \\ Program Studi Teknik Industri, Fakultas Teknik Universitas Kristen Maranatha, Bandung \\ E-mail: dewichristinasyamsir@live.com, elty.sarvia@eng.maranatha.edu
}

\begin{abstract}
Abstrak
ATM adalah alat elektronik berbasis komputer yang membantu nasabah melakukan transaksi keuangan tanpa harus datang ke bank. Sebagian besar nasabah memilih menggunakan ATM daripada mendatangi bank, sehingga kualitas ATM baik layanan maupun kondisi fisiknya harus ditingkatkan. Kondisi fisik ATM harus dapat memberikan rasa nyaman dan aman kepada nasabah. ATM "Bank A"Setrasari, Bandung merupakan salah satu ATM dengan kondisi fisik yang kurang memadai sehingga perlu dirancang sesuai dengan ilmu ergonomi.Tujuan Penelitian ini adalah menganalisa desain mesin ATM "Bank A" saat ini serta mendesain ulang mesin ATM sesuai dengan aspek ergonomi, menganalisa tata letak fasilitas di dalam ruangan ATM yang menunjang kebersihan ruangan dan memperbaiki standar keamanan bagi mesin ATM pada ATM “Bank A"di Setrasari, Bandung. Usulan yang diberikan adalah mengganti warna tulisan pada screen/layar monitor menjadi putih, mengganti desain penutup tombol numerik pada lokasi ATM yang sepi atau membuka penutup tombol numerik pada lokasi ATM yang ramai, merelokasi letak tempat pengambilan uang, mengganti tempat sampah, mengganti handle pintu, dan merancang ulang tata letak ruangan. Sedangkan letak layar monitor tidak dilakukan rancang ulang karena alasan keamanan. Selain itu diusulkan penambahan bel di dalam ruangan, stiker pada dinding ruangan, serta perawatan terhadap fasilitas-fasilitas yang terdapat di ATM oleh pihak bank agar fasilitasfasilitas tersebut dapat berfungsi secara optimal.
\end{abstract}

Kata kunci : ATM, Kondisi fisik, Ergonomi

\begin{abstract}
ATM is a computerized electronic equipment that help customers make financial transactions without come to the bank. Most of the customers choose to use the ATM instead go to the bank, so the ATM quality of service and physical condition should be improved. The physical condition of the ATM should be able to provide comfort and security to customers. "Bank A"ATM Setrasari, Bandung is one of the ATM with inadequate physical conditions that need to be designed based on ergonomics. The Purpose of this study is to analyze the current ATM bank design and redesign the ATM machine based on aspect of ergonomics, analyze the layout of facilities in the ATM room that support the cleanliness of the room and improve security standards for ATM machines at "Bank A" ATM in Setrasari, Bandung. The proposed design are changing the color of text on the screen to white, replace the cover design of the keypad on a deserted locations or opening the cover on a crowded location, relocate the layout of the cash dispenser, changing the trash bin, replace the door handle, and redesigning the layout of the room. The screen layout can not be changed for security reasons. Beside that, proposed an additional bell in the room, sticker on the wall room, as well as the maintenance of the facilities available at the ATM by the bank so that these facilities can function optimally.
\end{abstract}

Key word : ATM, Physical condition, Ergonomic 


\section{Pendahuluan}

ATM yang dalam bahasa Indonesia dikenal dengan nama Anjungan Tunai Mandiri adalah sebuah alat elektronik berbasis komputer yang membantu nasabah dalam melakukan transaksi keuangan tanpa harus datang ke bank. Kemudahan akses keuangan yang ditawarkan oleh ATM serta lokasi yang mudah dijangkau membuat sebagian besar nasabah lebih memilih menggunakan ATM daripada harus mendatangi bank itu sendiri. Hal ini menyebabkan ATM menjadi perwakilan bank yang lebih dekat ke masyarakat daripada kantor bank. Oleh karena itu, bank harus meningkatkan kualitas ATM baik berupa layanan maupun tampilan fisiknya sehingga kebutuhan nasabah dalam bertransaksi dapat terpenuhi dan dapat menampilkan kepada masyarakat luas standar kualitas layanan yang lebih tinggi dibanding bank lain.

Namun pada kenyataannya, bank seringkali hanya fokus pada kualitas layanan tetapi kurang memperhatikan fasilitas fisik. ATM "Bank A"di Setrasari, Bandung merupakan salah satu ATM dimana tidak semua fasilitas fisiknya sesuai dengan ilmu ergonomi. Adapun fasilitas fisik yang kurang mendapat perhatian dari pihak bank yaitu desain monitor dan tombol mesin ATM, ukuran mesin ATM, tata letak ruangan ATM, letak ruangan ATM yang lebih rendah daripada sekitarnya menyebabkan nasabah merasa kurang aman pada saat melakukan transaksi karena dapat terlihat dengan jelas dari luar, tidak terdapat kunci pengaman pintu di dalam ruangan ATM, pencahayaan, temperatur dan kebersihan di dalam ruangan ATM serta fasilitas yang menunjang keselamatan dan keamanan nasabah pada saat menggunakan ATM.

Apabila hal-hal tersebut tidak dirancang dengan baik maka nasabah akan mengalami kesulitan dalam mengoperasikan mesin ATM dan merasa tidak nyaman menggunakan ATM. Ketidaknyamanan tersebut mengakibatkan sering terjadi kesalahan pada saat melakukan transaksi di ATM seperti salah menekan tombol karena tombol yang tidak terlihat jelas atau kartu ATM tertinggal/tertelan. Pada akhirnya, hal ini menyebabkan tingkat kepuasan nasabah terhadap bank tersebut menurun sehingga nasabah beralih ke bank lain yang dapat memberikan pelayanan yang lebih baik.

Adapun yang menjadi batasan dalam penelitian ini adalah :

- Data anthropometri yang dipakai dalam perancangan ini diambil dari buku "Ergonomi, Konsep Dasar, dan Aplikasinya" karangan Eko Nurmianto 2004.

- Perancangan mesin ATM hanya mencakup kondisi fisik seperti desain serta ukuran dari monitor, tombol, dan mesin ATM serta ruangan ATM.

- Lingkungan fisik yang diamati meliputi temperatur, kelembaban, pencahayaan, sirkulasi udara, bau-bauan, dan warna. Tidak membahas mengenai kebisingan karena ruangan ATM "Bank A" Setrasari, Bandung telah menggunakan kaca kedap suara. Tidak membahas mengenai getaran mekanis karena di sekitar ATM "BANK A" Setrasari, Bandung tidak terdapat peralatan yang menimbulkan getaran mekanis.

- Tidak membahas mengenai luas, tinggi, dan ukuran monitor ruangan ATM.

- Analisa tentang hasil perancangan tidak membahas mengenai analisa ekonomi, analisa legalisasi, analisa pemasaran, dan software yang digunakan pada mesin ATM.

\section{Tinjauan Pustaka}

Istilah "ergonomi" berasal dari bahasa latin yaitu ERGON (KERJA) dan NOMOS (HUKUM ALAM) dan dapat didefinisikan sebagai studi tentang aspek-aspek manusia dalam lingkungan yang ditinjau secara anatomi, fisiologi, psikologi, engineering, manajemen dan desain atau perancangan. Ergonomi berkenaan pula dengan optimasi, efisiensi, kesehatan, keselamatan dan kenyamanan manusia di tempat kerja, di rumah dan tempat rekreasi. Di dalam ergonomi dibutuhkan studi tentang sistem dimana manusia, fasilitas kerja dan lingkungannya saling berinteraksi dengan tujuan utama yaitu menyesuaikan suasana kerja dengan manusianya (Nurmianto, 2004). 
Manusia sebagai makhluk sempurna tetap tidak luput dari kekurangan, dalam arti segala kemampuannya masih dipengaruhi oleh beberapa faktor. Faktor-faktor tersebut dapat berasal dari diri sendiri (intern), dapat juga dari pengaruhluar (ekstern). Salah satu faktor yang berasal dari luar adalah kondisi lingkungankerja, yaitu semua keadaan yang terdapat di sekitar tempat kerja sepertitemperatur, kelembaban udara, sirkulasi udara, pencahayaan, kebisingan, getaran mekanis, bau-bauan, warna dan lain-lain. Hal-hal tersebut dapat berpengaruh secara signifikan terhadap hasil kerja manusia.(Wignjosoebroto, 1995)

Secara umum tujuan dari penerapan ergonomi, antara lain:

1. Meningkatkan kesejahteraan fisik dan mental melalui upaya pencegahan cidera dan penyakit akibat kerja, menurunkan beban kerja fisik dan mental, mengupayakan promosi dan kepuasan kerja;

2. Meningkatkan kesejahteraan sosial melalui peningkatan kualitas kontak sosial dan mengkoordinasi kerja secara tepat, guna meningkatkan jaminan sosial baik selama kurun waktu usia produktif maupun setelah tidak produktif;

3. Menciptakan keseimbangan rasional antara aspek teknis, ekonomis, dan antropologis dari setiap sistem kerja yang dilakukan sehingga tercipta kualitas kerja dan kualitas hidup yang tinggi. (Tarwaka. dkk, 2004).

Data anthropometri yang menyajikan data ukuran dari berbagai macam anggota tubuh manusia dalam persentil tertentu akan sangat besar manfaatnya pada saat suatu rancangan produk atupun fasilitas kerja akan dibuat. Penerapan data anthropometri ini akan dapat dilakukan jika tersedia nilai mean (rata-rata) dan SD (standar deviasi) dari suatu distribusi normal.

Mengingat bahwa keadaan dan ciri fisik dipengaruhi oleh banyak faktor sehingga berbeda satu sama lainnya maka terdapat tiga prinsip dalam pemakai data tersebut, yaitu : perancangan fasilitas berdasarkan individu yang ekstrim, perancangan fasilitas yang bisa disesuaikan, dan perancangan fasilitas berdasarkan harga rata-rata pemakainya.

Prinsip perancangan fasilitas berdasarkan individu ekstrim. Perancangan fasilitas berdasarkan individu ekstrim ini terbagi atas dua yaitu perancangan berdasarkan individu terbesar (pada penelitian ini berdasarkan data anthropometri terbesar). Kedua adalah perancangan fasilitas berdasarkan individu terkecil (data anthropometri terkecil).

Perancangan fasilitas yang bisa disesuaikan. Prinsip ini digunakan untuk merancang suatu fasilitas agar fasilitas tersebut bisa menampung atau bisa dipakai dengan enak dan nyaman oleh semua orang yang mungkin memerlukannya.

Perancangan fasilitas berdasarkan harga rata-rata para pemakainya. Prinsip ini hanya digunakan apabila perancangan berdasarkan harga ekstrim tidak mungkin dilaksanakan dan tidak layak jika kita menggunakan prinsip perancangan fasilitas yang bisa disesuaikan. Prinsip berdasarkan harga ekstrim tidak mungkin dilaksanakan bila lebih banyak rugi daripada untungnya; artinya hanya sebagain kecil dari dari orang-orang yang merasa enak dan nyaman ketika menggunakan fasilitas tersebut. Sedangkan jika fasilitas tersebut dirancang berdasarkan fasilitas yang bisa disesuaikan, tidak layak karena terlalu mahal biayanya (Sutalaksana, 1979).

Display merupakan bagian dari lingkungan yang perlu memberi informasi kepada pekerja agar tugas-tugasnya menjadi lancar (Sutalaksana,1979). Arti informasi disini cukup luas, menyangkut semua rangsangan yang diterima oleh indera manusia baik langsung maupun tidak langsung. Informasi-informasi yang dibutuhkan sebelum membuat display, diantaranya:

- Tipe teknologi yang digunakan untuk menampilkan informasi.

- Rentang total dari variabel mengenai informasi mana yang akan ditampilkan.

- Ketepatan dan sensitivitas maksimal yang dibutuhkan dalam pengiriman informasi.

- Kecepatan total dari variabel yang dibutuhkan dalam pengiriman informasi. 
- Minimasi kesalahan dalam pembacaan display.

- Jarak normal dan maksimal antara display dan pengguna display.

- Lingkungan dimana display tersebut digunakan.

Display merupakan bagian dari lingkungan yang perlu memberi informasi kepada pekerja agar tugas-tugasnya menjadi lancar (Sutalaksana,1979). Arti informasi disini cukup luas, menyangkut semua rangsangan yang diterima oleh indera manusia baik langsung maupun tidak langsung. Informasi-informasi yang dibutuhkan sebelum membuat display, diantaranya:

- Tipe teknologi yang digunakan untuk menampilkan informasi.

- Rentang total dari variabel mengenai informasi mana yang akan ditampilkan.

- Ketepatan dan sensitivitas maksimal yang dibutuhkan dalam pengiriman informasi.

- Kecepatan total dari variabel yang dibutuhkan dalam pengiriman informasi.

- Minimasi kesalahan dalam pembacaan display.

- Jarak normal dan maksimal antara display dan pengguna display.

- Lingkungan dimana display tersebut digunakan.

\section{Metodologi Penelitian}

Pengumpulan data dilakukan dengan mengadakan pengamatan langsung ke ATM "Bank A"dan membagikan kuesioner kepada para nasabah yang menggunakan ATM. Tujuan dari kuesioner ini adalah untuk mengetahui kelebihan-kelebihan dan kekurangan dari mesin ATM "Bank A" saat ini.

Kuesioner ini terdiri dari 2 bagian, bagian pertama menanyakan tentang profil responden dan bagian kedua berisi pernyataan tentang hal-hal yang menjadi perhatian dalam perancangan ulang mesin ATM dan ruangannya. Data-data yang dikumpulkan adalah data umum perusahaan, tipe dari mesin ATM "Bank A" Bandung dan ukuran dari mesin ATM tersebut, desain penempatan bagianbagian dari mesin ATM aktual, kondisi ruangan ATM, tata letak, lingkungan fisik kerja dan perangkat yang menunjang keamanan fasilitas yang ada di dalam ruangan ATM saat ini. Hasil kuesioner dari pernyataan dengan jawaban Setuju $\leq 50 \%$ dianggap belum baik dan dirangkum menjadi kelemahan mesin dan ruangan ATM.

Data anthropometri diambil dari buku "Ergonomi, Konsep Dasar, dan Aplikasinya" karangan Eko Nurmianto 2004. Ukuran anthropometri yang akan digunakan dalam merancang ulang mesin ATM dan ruangan ATM merupakan ukuran anthropometri masyarakat Indonesia.

Data temperatur, kelembaban dan pencahayaan yang dikumpulkan, diukur selama tiga hari setiap dua jam mengingat ATM beroperasi selama 24 jam. Temperatur dan kelembaban diukur ditempat nasabah berdiri pada saat menggunakan mesin ATM, sedangkan pencahayaan diukur di layar monitor dan tombol numerik mesin ATM. Analisis mengenai kecelakaan yang pernah terjadi dan kecelakaan yang berpotensi terjadi di ATM "Bank A", Bandung. 


\section{Pengumpulan Data}

\subsection{Desain Penempatan Bagian-bagian dari Mesin ATM Aktual}

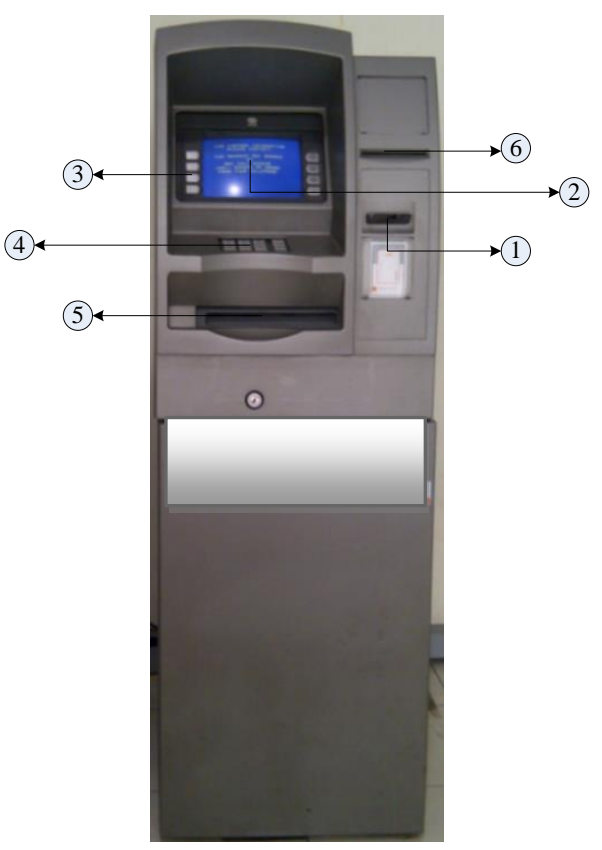

Keterangan Gambar:

1 : Card Reader/Mesin Pembaca Kartu

2 : Screen/Layar Monitor

3 : Screen Button/Tombol untuk Layar

4:Keypad/Tombol Numerik

5:Cash Dispenser/Tempat Pengambilan Uang

6 : Receipt Printer/Pencetak Resi

Tinggi Bagian-bagian Mesin ATM dari Lantai :

Card Reader/Mesin Pembaca Kartu: 0,98 m

Screen/Layar Monitor: 1,12 m

Keypad/Tombol Numerik: 0,93 m

Cash Dispenser/Tempat Pengambilan Uang: 0,8 m

Receipt Printer/Pencetak Resi: 1,05 m

Gambar 1. Bagian-bagian dari Mesin ATM

\section{Desain Screen/Layar MonitorAktual}

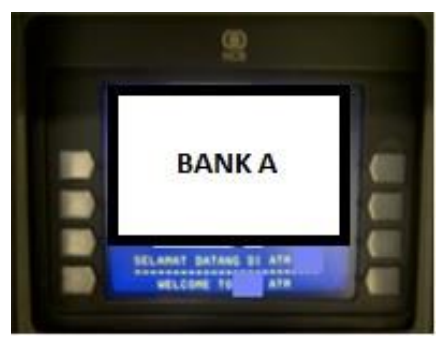

Warna background Screen/Layar Monitor: Biru Warna tulisan Screen/Layar Monitor: Kuning Ukuran Tulisan Screen/Layar Monitor: Font 36 Ukuran Screen/Layar Monitor: 24x18 cm Ukuran Screen Button/Tombol: 2,5x1,5cm Jarak antara Screen Button/Tombol: 0,7 cm

Gambar 2. Screen/Layar Monitor Aktual

\section{DesainKeypad/Tombol NumerikAktual}

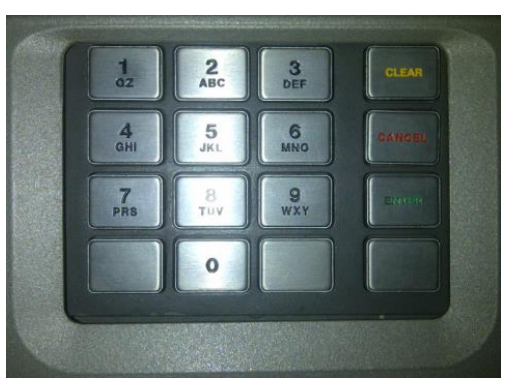

Gambar 3. Keypad/Tombol Numerik ATM Aktual (Sumber ATM "Bank A”Setrasari, Bandung)

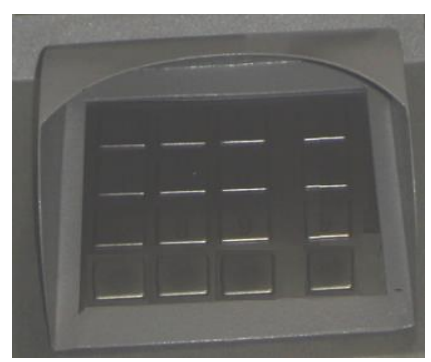

Gambar 4. Penutup Keypad/Tombol Numerik ATM Aktual (Sumber ATM "Bank A"Setrasari, Bandung) 


\subsection{Tata Letak Ruangan ATM Aktual}

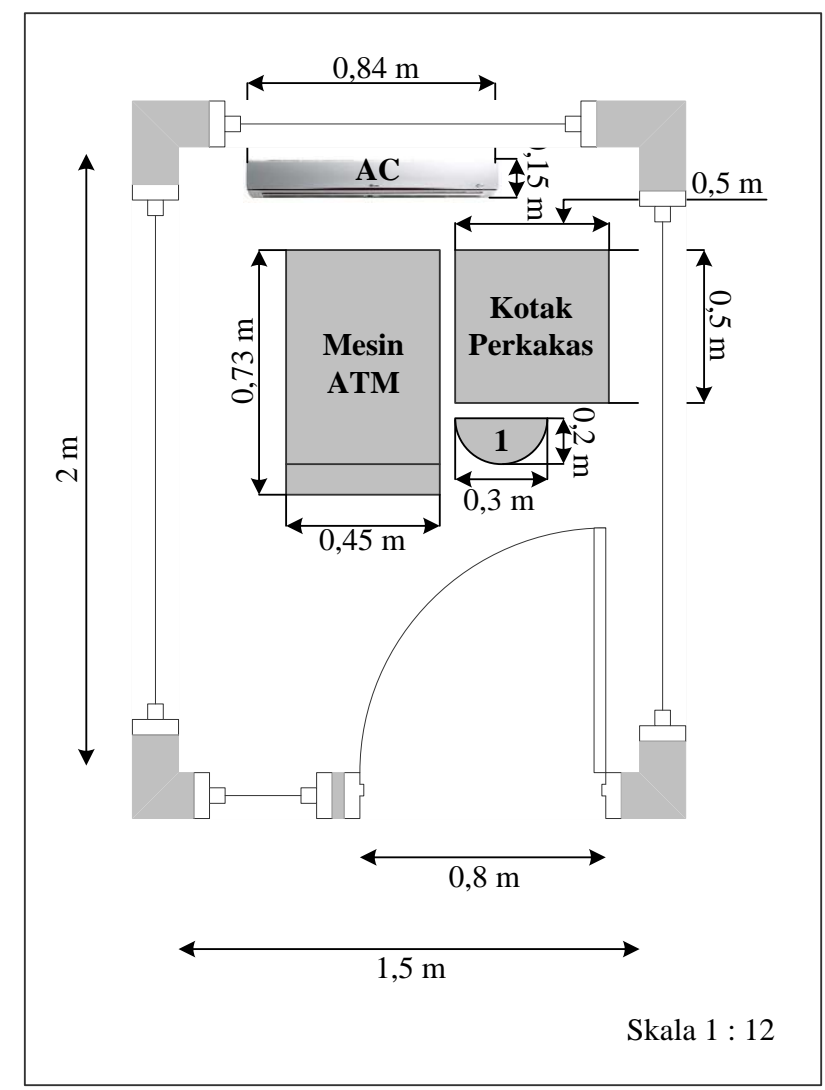

Gambar 5. Tata Letak Ruangan ATM Saat Ini (Sumber ATM “Bank A”Setrasari, Bandung)

Keterangan Tambahan:

$1 \rightarrow$ Tempat sampah

\subsection{Fasilitas yang Disediakan oleh Pihak Bank yang Menunjang Keamanan Mesin ATM}

1 Cash Handler Sensor(sensor bila ada uang tersangkut di mesin).

2 Resi Print Sensor

3 Mesin ATM memiliki kertas resi(kertas bukti penarikan/transfer), dan apabila kertas dan kartu itu tidak ditarik atau diambil maka akan masuk ke dalam mesin ATM lagi, hal ini tergantung pada pihak IT yang melakukan setting terhadap mesin ATM tersebut.

4 Safe Door Lock (sensor bila pintu dibuka paksa)

5 Berat mesin ATM yaitu $400 \mathrm{~kg}$ sehingga mesin cukup berat apabila dipindahkan.

6 Pada sisi bawah mesin ATM terdapat anchor (sejenis pengunci ke tanah), ini berguna agar mesin ATM ini tidak bisa diangkat, apabila di angkat maka lantai harus dirusak terlebih dahulu.

7 Alarm Sensoryang berfungsi apabila mesin ATM bergeser maka alarm akan berbunyi.

8 Kamera CCTV (Closed Circuit Television)

9 Televisi signal yang bersifat tertutup, tidak seperti televisi biasa yang merupakan sinyal siaran. Dalam arti mudah berarti Perangkat Televisi Nirkabel yang digunakan untuk mengambil gambar.

10 Umumnya setiap 5 bulan dilakukan opname atau pembersihan ATM, pengecekan sparepart, maintenance, dan lain-lainnya. 


\subsection{Fasilitas yang Disediakan oleh Pihak Bank dalam Menunjang Keselamatan Nasabah pada ATM "Bank A"di Setrasari, Bandung Saat Ini}

1. Apabila nasabah lupa menarik uang, maka akan terdengar bunyi "beep beep" yang mengingatkan nasabah, dan jika uang tetap tidak diambil maka uang akan tetap menggantung di luar dan saldo nasabah akan berkurang.

2. Kamera CCTV (Closed Circuit Television)

Televisi signal yang bersifat tertutup, tidak seperti televisi biasa yang merupakan sinyal siaran. Dalam arti mudah berarti Perangkat Televisi Nirkabel yang digunakan untuk mengambil gambar.

2. Pada ATM terdapat kabel grounding ke tanah agar mesin ATM tidak menyetrum.

3. Temperature Sensor (sensor bila temperatur overheat)

\subsection{Kecelakaan Yang Pernah Terjadi}

1. Kasus penggandaan kartu ATM nasabah dengan menggunakan alat perekam pada mesin ATM.

2. Ledakan ATM "Bank A"yang berada di Bandung yang mengakibatkan ruangan dan mesin ATM terbakar, selain itu pintu ATM terlempar beberapa meter.

3. Pencurian uang dan mesin ATM "BANK A" di Jakarta Timur.

4. Pembobolan mesin anjungan tunai mandiri (ATM) Bank "Bank A" di kota Bekasi.

\section{Analisis}

\subsection{Analisis Data Temperatur, Kelembaban dan Pencahayaan di dalam Ruangan ATM}

Berdasarkan hasil pengumpulan data temperatur selama 3 hari setiap 2 jam, didapatkan bahwa temperatur dalam ruangan mesin ATM "Bank A", Bandung pada pagi hari berkisar $19-21^{\circ} \mathrm{C}$, siang hari berkisar $22-23^{\circ} \mathrm{C}$, sore hari berkisar $23-24^{\circ} \mathrm{C}$ dan pada malam hari berkisar $20-24^{\circ} \mathrm{C}$. Berdasarkan Keputusan Menteri Kesehatan Republik Indonesia No. 1405/MENKES/SK/XI/2002 didapatkan bahwa produktivitas manusia akan mencapai tingkat yang paling tinggi pada temperatur sekitar $18-28^{\circ} \mathrm{C}$. Hal ini menunjukkan bahwa temperatur di dalam ruangan ATM "Bank A", Bandung pada pagi, siang, sore dan malam hari masih berada dalam batas normal.

Berdasarkan hasil pengumpulan data kelembaban selama 3 hari setiap 2 jam, didapatkan bahwa kelembaban dalam ruangan mesin ATM "Bank A", Bandung pada pagi hari berkisar $72-74 \%$, siang hari berkisar $65-72 \%$, sore hari berkisar $55-70 \%$, dan pada malam hari berkisar $63-71 \%$. Menurut Dr. Suma'mur, kelembaban yang memberikan kenyamanan berkisar antara $45 \%-75 \%$. Hal ini menunjukkan bahwa kelembaban di dalam ruangan ATM "Bank A"di Setrasari, Bandung masih berada dalam batas normal.

Berdasarkan hasil pengumpulan data pencahayaan selama 3 hari setiap 2 jam, didapatkan bahwa pencahayaan pada layar monitor dan tombol numerik sama. Hal ini mungkin disebabkan karena titik tempat pengukuran masih berada dalam satu area. Pencahayaan dalam ruangan mesin ATM "Bank A", Bandung pada pagi hari berkisar 285 - 323 lux, siang hari berkisar 241 - 261 lux, sore hari berkisar 243 - 299 lux, dan pada malam hari berkisar 281 - 301 lux. Jenis kegiatan yang dilakukan dalam ruangan mesin ATM dikategorikan ke dalam kerja umum dengan detail yang wajar. Berdasarkan KEPMENKES RI. No. 1405/MENKES/SK/XI/02 pencahayaan yang dibutuhkan di dalam ruangan ATM minimal 100 lux dan berdasarkan Prasasto Satwiko pencahayaan yang dibutuhkan di dalam ruangan ATM berkisar antara 200-300 lux. Hal ini menunjukkan bahwa pencahayaan di dalam ruangan ATM "Bank A"di Setrasari, Bandung masih berada dalam batas normal.

Di dalam ruangan ATM "Bank A" Setrasari, Bandung terdapat AC (Air Conditioner). AC ini berfungsi mengatur suhu udara dan kelembaban udara, selain itu juga berfungsi mengatur 
kebersihan udara di dalam ruangan seperti membasmi jamur, mikropartikel dan molekul-molekul pembangkit alergi contohnya debu, serta berfungsi mengatur sirkulasi udara sehingga dapat menghilangkan bau-bauan yang tidak sedap di dalam ruangan. Oleh karena itu, tidak terdapat baubauan yang dapat mengganggu kenyamanan nasabah.

Warna jingga merupakan gambaran "Bank A" baru yang modern. Warna jingga pada dinding ini sebenarnya kurang cocok digunakan pada ruangan yang kecil karena memberikan efek sangat dekat sehingga ruangan terkesan lebih sempit dari yang sebenarnya, dan disamping itu warna jingga juga memberikan efek sangat panas. Sedangkan bangunan tempat ATM "Bank A" Setrasari, Bandung yang terbuat dari beton yang dicat berwarna putih dan lantai ruangan terbuat dari keramik berwarna putih. Secara visual, warna putih ini memberikan ilusi bahwa ruangan tersebut lebih tinggi daripada yang sebenarnya, sehingga cocok untuk diterapkan di ruang kecil untuk memberi kesan luas dan dapat menyeimbangkan penggunaan warna jingga pada dinding.

Tabel 1. Rangkuman Temperatur, Kelembaban dan Pencahayaan di dalam Ruangan ATM

\begin{tabular}{|c|c|c|c|c|}
\hline \multirow{2}{*}{ Waktu } & \multirow{2}{*}{ Temperatur $\left({ }^{\mathbf{0}} \mathbf{C}\right)$} & \multirow{2}{*}{ Kelembaban (\%) } & \multicolumn{2}{|c|}{ Pencahayaan (Lux) } \\
\cline { 3 - 5 } & & & Monitor & Tombol Numerik \\
\hline Pagi & $19-21$ & $72-74$ & $285-323$ & $285-323$ \\
\hline Siang & $22-23$ & $65-72$ & $241-261$ & $241-261$ \\
\hline Sore & $23-24$ & $55-70$ & $243-299$ & $243-299$ \\
\hline Malam & $20-24$ & $63-71$ & $281-301$ & $281-301$ \\
\hline
\end{tabular}

\section{Perancangan dan Analisis}

Berdasarkan hasil kuesioner, diperoleh 9 point yang menjadi kelemahan dari ATM "BANK A" di Setrasari, Bandung sekarang ini. Kelemahan-kelemahan ini seringkali menyebabkan konsumen mengalami kesulitan dalam mengoperasikan mesin ATM dan merasa tidak nyaman menggunakan ATM. Ketidaknyamanan tersebut mengakibatkan sering terjadi kesalahan pada saat melakukan transaksi di ATM seperti salah menekan tombol karena tombol yang tidak terlihat jelas atau kartu ATM tertinggal/tertelan. Hal ini bisa saja menyebabkan tingkat kepuasan nasabah terhadap bank tersebut menurun sehingga nasabah beralih ke bank lain yang dapat memberikan pelayanan yang lebih baik. Oleh karena itu diperlukan adanya rancangan ulang bagi mesin dan ruangan ATM "Bank A" di Setrasari, Bandung agar dapat menambah kenyamanan bagi para konsumen.

Kelemahan mesin dan ruangan ATM berdasarkan hasil kuesioner:

1. Nasabah merasa tidak leluasa pada saat keluar dari dalam ruangan ATM.

2. Nasabah merasa tidak nyaman dengan temperatur di dalam ruangan ATM.

3. Nasabah merasa ruangan ATM belum bersih.

4. Nasabah merasa fasilitas keamanan di dalam ruangan ATM belum cukup.

5. Nasabah merasa fasilitas keselamatan di dalam ruangan ATM belum cukup.

6. Letak layar monitor terlalu ke bawah.

7. Tombol numerik tidak dapat terlihat dengan jelas.

8. Letak tempat pengambilan uang belum tepat.

9. Warna tulisan pada layar monitor belum tepat. 
Tabel 2. Perbaikan/Perancangan yang Dilakukan Berdasarkan Hasil Kuesioner

\begin{tabular}{|c|l|l|}
\hline No. & Kelemahan Mesin \& Ruangan ATM Berdasarkan Hasil Kuesioner & \\
\hline 1 & Letak screen /layar monitor & Analisis ulang letak screen/layar monitor \\
\hline 2 & Keypad/tombol numerik tidak dapat terlihat dengan jelas & Mengganti penutup keypad/tombol numerik \\
\hline 3 & Letak cash dispenser/tempat pengambilan uang belum tepat & Relokasi cash dispenser/tempat pengambilan uang \\
\hline 4 & Warna tulisan pada screen /layar monitor belum tepat & Rancang ulang warna tulisan pada screen /layar monitor \\
\hline 5 & Nasabah merasa tidak leluasa pada saat keluar dari dalam ruangan ATM & Perancangan ulang tata letak ruangan ATM \\
\hline 6 & Nasabah merasa tidak nyaman dengan temperatur di dalam ruangan ATM & Saran perawatan AC/pendingin ruangan bagi pihak Bank \\
\hline 7 & Nasabah merasa ruangan ATM belum bersih & Mengganti desain tempat sampah \\
\hline 8 & Nasabah merasa fasilitas keamanan di dalam ruangan ATM belum cukup & 1. Saran pemeriksaan dan pengawasan rutin oleh pihak Bank \\
\cline { 3 - 3 } & & 2. Mengatur ulang letak kamera CCTV \\
\hline 9 & Nasabah merasa fasilitas keselamatan di dalam ruangan ATM belum & Penambahan kunci slot dan bel di dalam ruangan ATM \\
\hline
\end{tabular}

Dalam perancangan mesin ATM dan ruangannya di ATM "Bank A" Setrasari, Bandung ini terdapat batasan-batasan yang menyebabkan hasil rancangan tidak dapat memenuhi semua aspek yang dibutuhkan manusia. Adapun batasan-batasan dalam perancangan ini adalah :

- Luas ruangan ATM

- Tinggi ruangan ATM

- Ukuran pintu

- Tinggi layar monitor mesin ATM

\subsection{Mesin ATM}

Tabel 3. Perbandingan antara ukuran anthropometri mesin ATM aktual dengan ukuran anthropometri masyarakat Indonesia.

\begin{tabular}{|c|c|c|c|c|c|c|c|c|c|c|c|c|c|}
\hline \multirow{2}{*}{$\begin{array}{l}\text { Nama } \\
\text { Produk }\end{array}$} & \multicolumn{2}{|l|}{ Dimensi } & \multirow{3}{*}{\begin{tabular}{|l|} 
Patokan \\
Rata-rata
\end{tabular}} & \multicolumn{4}{|c|}{ Data Anthropometri } & \multicolumn{2}{|c|}{ Allowance } & \multirow{2}{*}{\begin{tabular}{|c|} 
Ukuran \\
yang \\
Disarankan \\
\end{tabular}} & \multirow{2}{*}{$\begin{array}{c}\text { Selisih } \\
(\mathrm{mm})\end{array}$} & \multirow[b]{2}{*}{ Keterangan } & \multirow{2}{*}{$\begin{array}{c}\text { Keputusan } \\
\text { Akhir }\end{array}$} \\
\hline & Jenis & \begin{tabular}{|c|}
$\begin{array}{c}\text { Ukuran } \\
(\mathrm{mm})\end{array}$ \\
\end{tabular} & & Jenis & & ercentil & \begin{tabular}{|c|}
$\begin{array}{c}\text { Ukuran } \\
(\mathrm{mm})\end{array}$ \\
\end{tabular} & Jenis & \begin{tabular}{|c|} 
Ukuran \\
$(\mathrm{mm})$
\end{tabular} & & & & \\
\hline \multirow{8}{*}{$\begin{array}{l}\text { Mesin } \\
\text { ATM }\end{array}$} & \begin{tabular}{|lr} 
Tinggi & pusat \\
screen /layar & monitor \\
\end{tabular} & 1.120 & & $\begin{array}{l}\text { Tinggi } \\
\text { Mata }\end{array}$ & 50 & Wanita & 1446 & \begin{tabular}{|c|} 
Tebal \\
sepatu
\end{tabular} & 30 & 1.476 & 356 & \begin{tabular}{|lr} 
Tidak & diubah karena \\
alasan & keamanan \\
\end{tabular} & $\begin{array}{c}\text { Tidak } \\
\text { diperbaiki }\end{array}$ \\
\hline & $\begin{array}{|lr|}\text { Batas } & \text { tinggi } \\
\text { screen/layar } & \text { monitor } \\
\end{array}$ & 1.210 & Min & $\begin{array}{l}\text { Tinggi } \\
\text { Bahu }\end{array}$ & 5 & Wanita & 1184 & \begin{tabular}{|c|} 
Tebal \\
sepatu
\end{tabular} & 30 & 1.214 & 4 & \begin{tabular}{|rr} 
Tidak & diubah \\
alasan & keamanan \\
\end{tabular} & $\begin{array}{c}\text { Tidak } \\
\text { diperbaiki }\end{array}$ \\
\hline & Lebar layar monitor & 240 & Min & $\begin{array}{l}\text { Lebar } \\
\text { Bahu }\end{array}$ & 5 & Wanita & 342 & & & 342 & 102 & $\begin{array}{|cc|}\text { Lebar } & \begin{array}{l}\text { aktual sudah } \\
\text { baik }\end{array} \\
\end{array}$ & $\begin{array}{c}\text { Tidak } \\
\text { diperbaiki }\end{array}$ \\
\hline & \begin{tabular}{|lr} 
Card & reader \\
pembaca & kartu \\
\end{tabular} & 980 & Rata-rata & $\begin{array}{c}\text { Tinggi } \\
\text { Siku }\end{array}$ & 50 & Wanita & 957 & $\begin{array}{c}\text { Tebal } \\
\text { sepatu }\end{array}$ & 30 & 987 & 7 & Tidak & Diperbaiki \\
\hline & $\begin{array}{c}\text { Letak keypad /tombo } \\
\text { numerik }\end{array}$ & 930 & Rata-rata & $\begin{array}{l}\text { Tinggi } \\
\text { Siku }\end{array}$ & 50 & Wanita & 957 & $\begin{array}{c}\text { Tebal } \\
\text { sepatul }\end{array}$ & 30 & 987 & 57 & $\begin{array}{lr}\text { Tidak diubah karena } \\
\text { alasan } & \text { keamanan }\end{array}$ & $\begin{array}{c}\text { Tidak } \\
\text { diperbaiki }\end{array}$ \\
\hline & $\begin{array}{c}\text { Ukuran } \\
\text { keypad/tombol } \\
\text { numerik }\end{array}$ & 22 & Maks & $\begin{array}{c}\text { Lebar Jari } \\
\text { Telunjuk }\end{array}$ & 95 & Pria & 22 & & & 22 & 0 & Sesuai & $\begin{array}{c}\text { Tidak } \\
\text { diperbaiki }\end{array}$ \\
\hline & \begin{tabular}{|c|} 
Cash \\
dispenser/tempat \\
pengambilan uang
\end{tabular} & 800 & Rata-rata & $\begin{array}{l}\text { Tinggi } \\
\text { Siku }\end{array}$ & 50 & Wanita & 957 & $\begin{array}{c}\text { Tebal } \\
\text { sepatu }\end{array}$ & 30 & 987 & 187 & Tidak & Perbaiki \\
\hline & $\begin{array}{c}\text { Receipt } \\
\text { printer } / \text { pencetak } \quad \text { resi }\end{array}$ & 1.050 & Rata-rata & $\begin{array}{l}\text { Tinggi } \\
\text { Siku }\end{array}$ & 50 & Wanita & 957 & \begin{tabular}{|c|} 
Tebal \\
sepatu
\end{tabular} & 30 & 987 & 63 & Tidak & Perbaiki \\
\hline
\end{tabular}

\subsubsection{Letak Layar Monitor Pada Mesin ATM}

Berdasarkan hasil pengolahan data kuesioner, diketahui bahwa konsumen pengguna ATM "BANK A" Setrasari, Bandung merasa perlu menunduk pada saat membaca layar monitor. Hal ini disebabkan karena konsumen merasa letak layar monitor agak kebawah. Tinggi titik pusat layar monitor saat ini adalah $1,12 \mathrm{~m}$ dengan ukuran monitor $24 \mathrm{x} 18 \mathrm{~cm}$. Penempatan layar monitor yang agak ke bawah dimaksudkan agar layar monitor dapat tertutup oleh badan konsumen pada saat melakukan transaksi sehingga tidak mudah terlihat oleh orang lain yang berada di belakang konsumen.

Data antropometri yang digunakan untuk menentukan tinggi layar monitor adalah tinggi bahu, hal ini dimaksudkan agar layar monitor dapat tertutup oleh badan pengguna mesin ATM. Data yang digunakan adalah data masyarakat Indonesia jenis kelamin wanita dengan persentil 5 adalah 1,214 
$\mathrm{m}$. Hal ini berarti bahwa tinggi maksimum dari monitor bagian atas adalah 1,214 m. Dengan tinggi titik pusat layar monitor saat ini yaitu 1,12 m ditambah dengan setengah tinggi layar monitor yaitu $9 \mathrm{~cm}$, maka tinggi bagian atas layar monitor adalah $1,21 \mathrm{~m}$.

Dapat disimpulkan bahwa tinggi bagian atas layar monitor pada saat ini $(1,21 \mathrm{~m})$ sama dengan tinggi bahu masyarakat Indonesia $(1,214 \mathrm{~m})$ sehingga masih dapat menutupi layar monitor. Sedangkan lebar layar monitor $(24 \mathrm{~cm})$ masih tertutup dengan ukuran lebar bahu masyarakat Indonesia yaitu $44,2 \mathrm{~cm}$, oleh karena itu tidak perlu dilakukan perancangan ulang letak layar monitor saat ini.

\subsubsection{Letak Card Reader/Mesin Pembaca Kartu}

Data antropometri yang digunakan untuk menentukan letak card reader/mesin pembaca kartu adalah tinggi siku, hal ini dimaksudkan agar nasabah dapat dengan mudah memasukkan kartu ke dalam mesin ATM. Data yang digunakan adalah data masyarakat Indonesia jenis kelamin wanita dengan persentil 50 adalah $987 \mathrm{~mm}$ sedangkan tinggi aktual dari card reader/mesin pembaca kartu adalah $980 \mathrm{~mm}$. Hal ini berarti bahwa tinggi card reader/mesin pembaca kartu perlu dinaikkan sebanyak $7 \mathrm{~mm}$.

\subsubsection{Letak Tombol Numerik Pada Mesin ATM}

Maraknya penggandaan kartu yang dilakukan oleh oknum tertentu beberapa waktu yang lalu membuat pihak pengelola bank menambahkan penutup pada tombol numerik pada mesin ATM agar pada saat mengetik pin ATM tidak terlihat oleh kamera yang dipasang pada bagian tertentu. Penambahan penutup tombol numerik mesin ATM ini seringkali menyebabkan sebagian nasabah mengalami kesusahan dalam melihat tombol-tombol angka sehingga harus menunduk pada saat menekan tombol dan menyebabkan kesalahan pengetikan oleh nasabah.

Letak tombol numerik ini tidak dapat diubah karena mengikuti tinggi layar monitor dimana letak tombol numerik dibawah letak layar monitor.

Usulan yang dapat diberikan adalah:

\section{- Alternatif 1}

Untuk ATM yang berada di area kantor Bank atau yang berada di lokasi keramaian, penutup keypad/tombol numerik dapat dibuka karena ATM mendapat pengawasan yang ketat dari pihak Bank sehingga sangat sulit untuk dipasangi skimmer atau kamera oleh pihak-pihak tertentu.

\section{- Alternatif 2}

Mengganti desain penutup keypad/tombol numerik. Desain penutup keypad/tombol numerik yang dirancang ditujukan agar tidak menghalangi pandangan nasabah pada menggunakan keypad/tombol numerik tetapi dapat menunjang keamanan nasabah dalam bertransaksi. Sedangkan desain dan ukuran keypad dan ukuran tombol pada layar monitor pada mesin ATM "BANK A" Setrasari, Bandung telah sesuai dengan data antropometri orang Indonesia yaitu $2,2 \times 1,5 \mathrm{~cm}$.

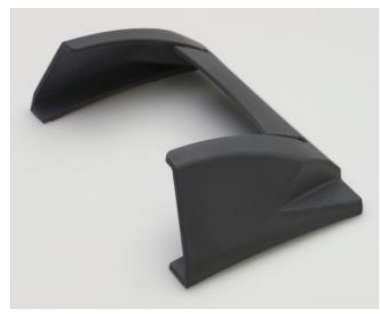

Tampak Samping

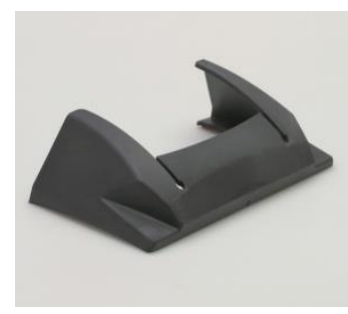

Tampak Belakang

Gambar 6.Tampak Samping dan Belakang Perancangan Penutup Keypad/Tombol Numerik 


\subsubsection{Letak Tempat Pengambilan Uang Pada Mesin ATM}

Berdasarkan hasil pengolahan data kuesioner, diketahui bahwa konsumen pengguna ATM "BANK A" Setrasari, Bandung merasa perlu menunduk pada saat mengambil uang dari mesin ATM. Letak tempat pengambilan uang yang agak jauh dari jangkauan mata konsumen dan sedikit menjorok ke dalam menyebabkan konsumen seringkali harus menunduk pada saat akan mengambil uang.

Beberapa desain letak tempat pengambilan uang yang disarankan:

\section{- Desain Alternatif 1 Letak Tempat Pengambilan Uang}

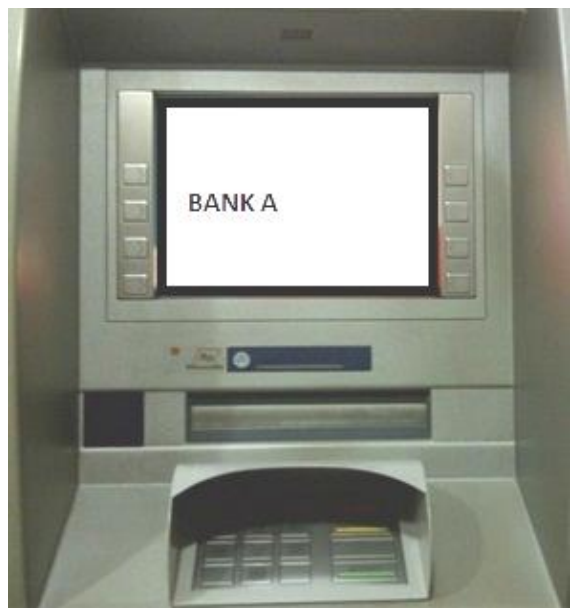

Gambar 7. Alternatif 1 Letak Tempat Pengambilan Uang

Pada perancangan letak tempat pengambilan uang alternatif 1 , tempat pengambilan uang diletakkan

diantara layar monitor dan tombol numerik.

Kelebihan dari desain perancangan letak tempat pengambilan uang alternatif 1:

- Letak tempat pengambilan uang mudah terlihat oleh konsumen sehingga tidak perlu menunduk pada saat mengambil uang.

- Meminimalisir kesalahan konsumen yang seringkali lupa mengambil uang

- Menghindari orang lain melihat kemungkinan jumlah uang yang ditarik.

\section{- Desain Alternatif 2 Letak Tempat Pengambilan Uang}

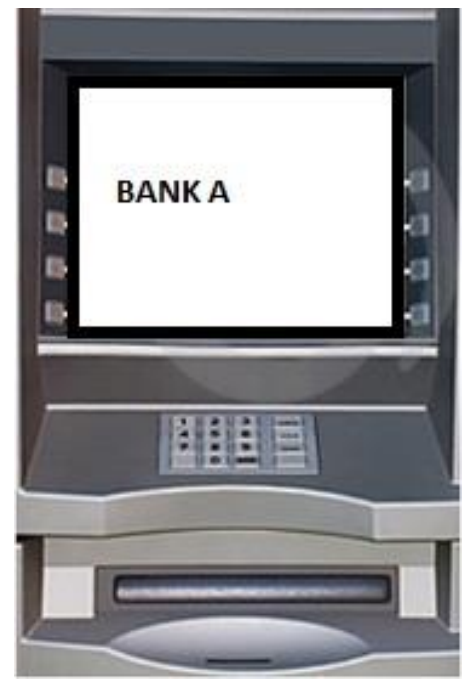

Gambar 8. Alternatif 2 Letak Tempat Pengambilan Uang 
Pada perancangan letak tempat pengambilan uang alternatif 2, tempat pengambilan uang diletakkan langsung di bawah tombol numerik dan tidak menjorok ke dalam.

Kelebihan dari desain perancangan letak tempat pengambilan uang alternatif 2:

- Letak tempat pengambilan uang mudah terlihat oleh konsumen sehingga tidak perlu menunduk pada saat mengambil uang.

- Meminimalisir kesalahan konsumen yang seringkali lupa mengambil uang

Tabel 4. Konsep Scoring untuk Letak Tempat Pengambilan Uang

\begin{tabular}{|c|c|c|c|c|c|}
\hline \multirow{3}{*}{ Parameter Penilaian } & \multirow{3}{*}{ Bobot } & \multicolumn{4}{|c|}{ Konsep Produk Yang Dibandingkan } \\
\hline & & \multicolumn{2}{|c|}{ Perancangan Alt 1} & \multicolumn{2}{|c|}{ Perancangan Alt 2} \\
\hline & & Nilai & Nilai x Bobot & Nilai & Nilai x Bobot \\
\hline Keamanan & 1 & 1 & 1 & 2 & 2 \\
\hline Kenyamanan & 2 & 1 & 2 & 2 & 4 \\
\hline \multicolumn{2}{|l|}{ Total Nilai (s) } & \multicolumn{2}{|r|}{3} & \multicolumn{2}{|r|}{6} \\
\hline \multicolumn{2}{|l|}{ Peringkat } & & 1 & \multirow{2}{*}{\multicolumn{2}{|c|}{$\begin{array}{l}\text { k dari nilai } 2 \\
\text { ih baik dari nilai } 1\end{array}$}} \\
\hline \multicolumn{2}{|l|}{$\begin{array}{l}\text { Keterangan : } \\
\text { Bobot : } \\
1=\text { Bobot pertama } \\
2=\text { Bobot kedua }\end{array}$} & & $\begin{array}{l}\text { Nilai : } \\
1=\text { Lebih } \\
2=\text { Tidak }\end{array}$ & & \\
\hline
\end{tabular}

Parameter yang digunakan dalam konsep scoring adalah parameter keamanan dan kenyamanan. Keamanan dipilih menjadi bobot pertama karena letak tempat pengambilan uang harus dapat memberikan rasa aman bagi pengguna dari resiko terlihat mengambil uang oleh orang lain. Kenyamanan dipilih menjadi bobot kedua karena letak tempat pengambilan uang harus dapat memberikan rasa nyaman pada pemakainya seperti tidak harus membungkuk pada saat mengambil uang.

Desain alternatif letak tempat pengambilan uang yang terpilih adalah alternatif 1 . Alternatif ini diusulkan karena kelebihan yang dimiliki yaitu letak tempat pengambilan uang mudah terlihat oleh konsumen sehingga tidak perlu menunduk pada saat mengambil uang, meminimalisir kesalahan konsumen yang seringkali lupa mengambil uang, dan menghindari orang lain melihat kemungkinan jumlah uang yang ditarik.

\subsubsection{Letak Receipt Printer/Pencetak Resi}

Data antropometri yang digunakan untuk menentukan letak receipt printer/pencetak resi adalah tinggi siku, hal ini dimaksudkan agar nasabah dapat dengan mudah mengambil bukti transaksi dari mesin ATM. Data yang digunakan adalah data masyarakat Indonesia jenis kelamin wanita dengan persentil 50 adalah $987 \mathrm{~mm}$ sedangkan tinggi aktual dari card reader/mesin pembaca kartu adalah $1.050 \mathrm{~mm}$, tetapi tinggi dari receipt printer/pencetak resi akan disesuaikan dengan tinggi card reader/mesin pembaca kartu karena letaknya diatas card reader/mesin pembaca kartu.

\subsubsection{Warna Tulisan Layar Monitor Pada Mesin ATM}

Pada mesin ATM "BANK A" Setrasari, Bandung, warna background pada layar monitor adalah biru yang cenderung terang karena adanya lampu dari dalam layar monitor. Sedangkan warna tulisan pada layar monitor adalah kuning. Desain monitor tersebut merupakan spesifikasi dari perusahaan Wincor Nixdorf.

Berdasarkan hasil pengolahan data kuesioner, diketahui bahwa konsumen pengguna ATM "BANK A" Setrasari, Bandung merasa warna tulisandari layar monitor mesin ATM belum baik. Hal ini dapat disebabkan karena penggunaan warna kuning pada warna tulisan di layar monitor yang tidak tepat sering memberikan efek menyilaukan terutama pada siang hari. Disamping itu warna 
background yang cenderung terang juga dapat menjadi faktor yang membuat mata silau pada siang hari karena memantulkan cahaya.

Warna background pada layar monitor yang diusulkan adalah warna biru yang agak gelap. Warna gelap tidak memantulkan cahaya dan warna tulisan pada layar monitor yang diusulkan yaitu warna putih karena warna tulisan yang cenderung terang akan terlihat dengan jelas apabila digabungkan dengan warna background yang sedikit gelap.

\subsubsection{Tempat Barang Bawaan Nasabah}

Pengguna ATM pada umumnya membawa barang-barang ke dalam ruangan ATM. Barang-barang bawaan tersebut dapat berupa tas, botol minuman, dan lain-lain. Pengguna ATM membutuhkan tempat yang dapat digunakan untuk menaruh barang-barang tersebut agar lebih mudah dalam melakukan transaksi. Oleh karena itu diberikan usulan desain tempat menaruh barang bawaan nasabah.

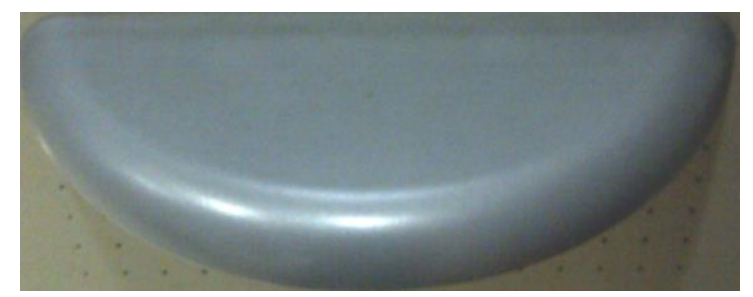

Gambar 9. Perancangan Desain Tempat Menaruh Barang

Ukuran dari tempat barang bawaan ini menggunakan ukuran rata-rata tas tangan wanita yaitu $30 \times$ $15 \mathrm{~cm}$ dengan bentuk melengkung agar aman bagi nasabah.

Kelebihan desain tempat menaruh barang bawaan:

- Bentuknya tidak tajam

- Terletak di depan nasabah sehingga barang nasabah tidak mudah tertinggal.

Kelemahan desain tempat menaruh barang bawaan:

- Tidak dapat menampung barang bawaan dengan ukuran besar.

\subsubsection{Desain Perancangan Mesin ATM}

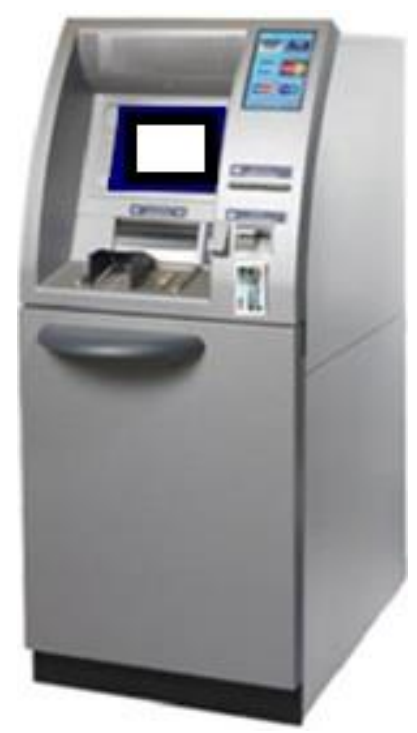

Gambar 10. Perancangan Mesin ATM 
Tinggi Bagian-bagian Mesin ATM dari Lantai :

Card Reader/Mesin Pembaca Kartu

: $0.987 \mathrm{~m}$

Screen/Layar Monitor

Keypad/Tombol Numerik

Cash Dispenser/Tempat Pengambilan Uang

: $1,03-1,21 \mathrm{~m}$

$: 0,92 \mathrm{~m}$

: $0,97 \mathrm{~m}$

Receipt Printer/Pencetak Resi

: $1,05 \mathrm{~m}$

Warna background Screen/Layar Monitor

: Biru

Warna tulisan Screen/Layar Monitor

: Putih

Ukuran TulisanScreen/Layar Monitor

: Font 36

Ukuran Screen/Layar Monitor

: $24 \times 18 \mathrm{~cm}$

Ukuran Screen Button/Tombol untuk Layar Monitor

$: 2,5 \times 1,5 \mathrm{~cm}$

Jarak antaraScreen Button/Tombol untuk Layar Monitor

$: 0,7 \mathrm{~cm}$

Ukuran Keypad/Tombol Numerik

Jarak antaraKeypad/Tombol Numerik

$: 0,2 \mathrm{~cm}$

\subsubsection{Perbandingan ATM Aktual dengan ATM Usulan}

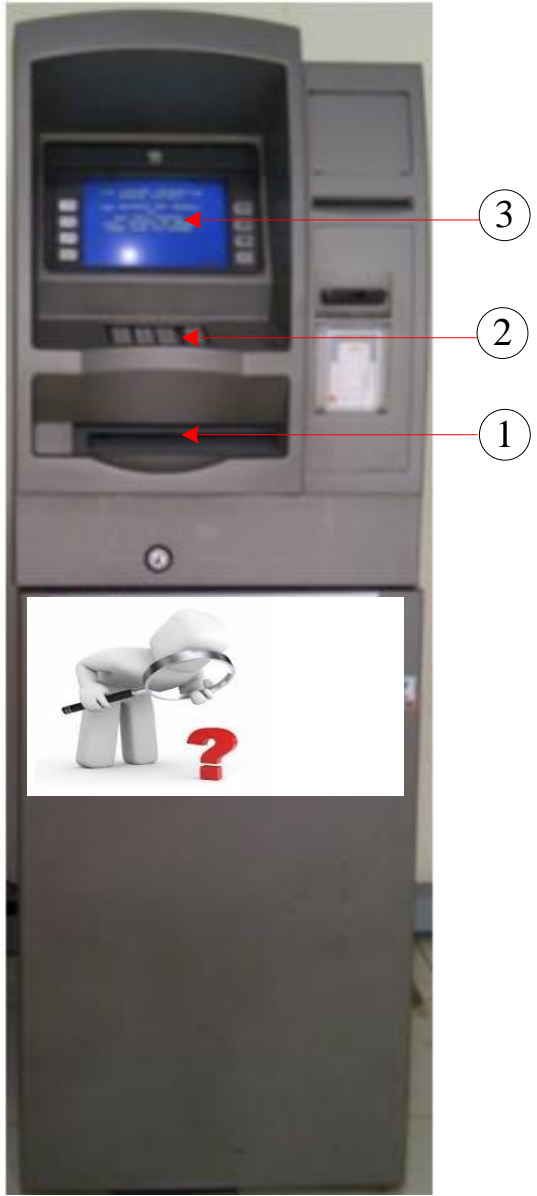

Mesin ATM Aktual

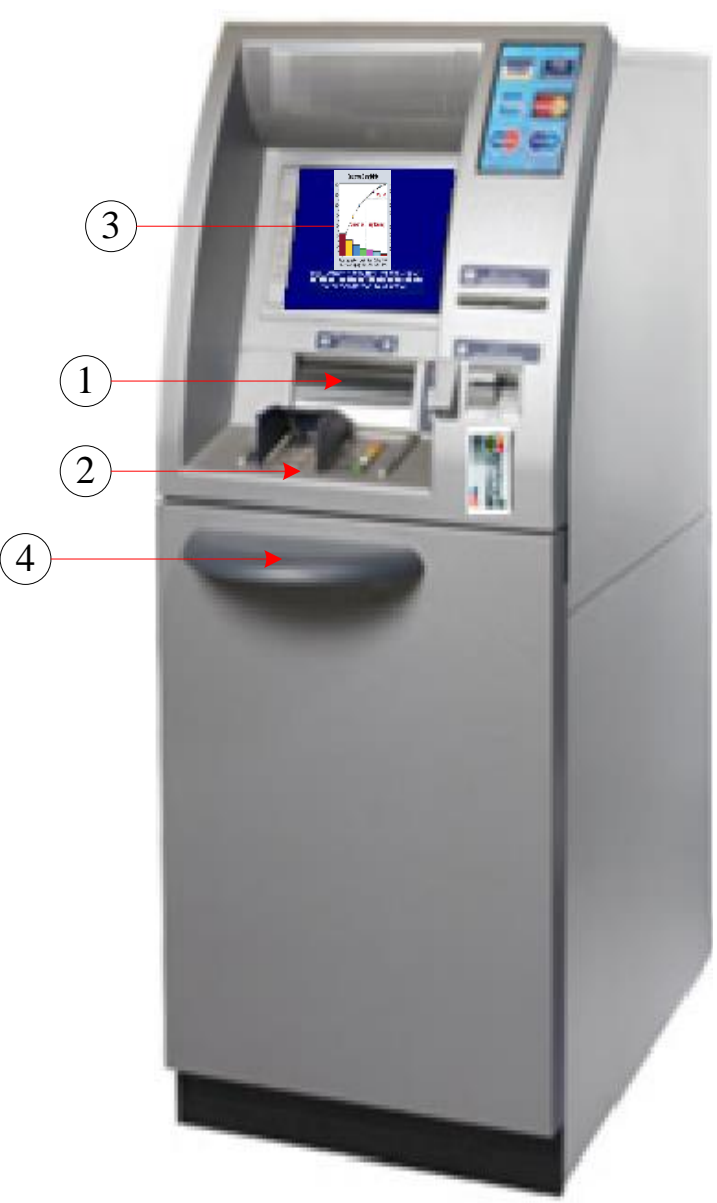

Mesin ATM Usulan

Gambar 11. Perbandingan ATM Aktual dengan ATM Usulan

Keterangan :

1. Letak cash dispenser/tempat pengambilan uang direlokasi

2. Penggantian penutup keypad/tombol numerik

3. Penggantian warna tulisan pada screen/layar monitor

4. Penambahan tempat menaruh barang bawaa 


\subsection{Ruangan ATM}

Tabel 5. Perbandingan Antara Ukuran Anthropometri Ruangan ATM Aktual dengan Ukuran Anthropometri Masyarakat Indonesia.

\begin{tabular}{|c|c|c|c|c|c|c|c|c|c|c|c|c|c|}
\hline \multirow[b]{2}{*}{$\begin{array}{l}\text { Nama } \\
\text { Produk }\end{array}$} & \multicolumn{2}{|l|}{ Dimensi } & \multirow[b]{2}{*}{ Patokan } & \multicolumn{4}{|c|}{ Data Anthropometri } & \multicolumn{2}{|c|}{ Allowance } & \multirow{2}{*}{\begin{tabular}{|c|} 
Ukuran \\
yang \\
Disarankan
\end{tabular}} & \multirow[b]{2}{*}{$\begin{array}{c}\text { Selisih } \\
(\mathrm{mm})\end{array}$} & \multirow[b]{2}{*}{ Keterangan } & \multirow[b]{2}{*}{$\begin{array}{c}\text { Keputusan } \\
\text { Akhir }\end{array}$} \\
\hline & Jenis & \begin{tabular}{|c|} 
Ukuran \\
$(\mathrm{mm})$
\end{tabular} & & Jenis & & rcentil & $\begin{array}{c}\text { Ukuran } \\
(\mathrm{mm})\end{array}$ & Jenis & \begin{tabular}{|c|} 
Ukuran \\
$(\mathrm{mm})$ \\
\end{tabular} & & & & \\
\hline \multirow{7}{*}{$\begin{array}{c}\text { Ruangan } \\
\text { ATM }\end{array}$} & Tinggi & 2.000 & Maks & $\mid$\begin{tabular}{cc} 
Tinggi & Tubuh \\
Posisi & Berdiri \\
\multicolumn{2}{c}{ Tegak }
\end{tabular} & 95 & Pria & 1.732 & $\begin{array}{c}\text { Tebal sepatu, } \\
\text { tinggi topi, \& } \\
\text { kelonggaran } \\
\text { dinamis }\end{array}$ & 130 & 1.862 & 138 & $\begin{array}{ccc}\text { Tinggi } & \text { pintu } & \text { aktual } \\
\text { sudah } & \text { lebih } & \text { baik }\end{array} \mid$ & $\begin{array}{c}\text { Tidak } \\
\text { diperbaiki }\end{array}$ \\
\hline & Lebar & 750 & Maks & Lebar Bahu & 95 & Pria & 466 & Lebar tas \& buku & 100 & 566 & 184 & $\begin{array}{rrr}\text { Lebar } & \text { pintu } & \text { aktual } \\
\text { sudah } & \text { lebih } & \text { baik } \\
\end{array}$ & $\begin{array}{c}\text { Tidak } \\
\text { diperbaiki }\end{array}$ \\
\hline & Panjang handle pintu & 130 & Maks & $\begin{array}{|lr|}\text { Lebar } & \text { Telapak } \\
\text { Tangan } & \text { (sampai } \\
\text { ibu } & \text { jari) } \\
\end{array}$ & 95 & Pria & 108 & Tebal kaos tangar & 10 & 118 & 12 & $\begin{array}{l}\text { Panjang handle pintu } \\
\text { aktual sudah lebih baik }\end{array}$ & $\begin{array}{c}\text { Tidak } \\
\text { diperbaiki }\end{array}$ \\
\hline & $\begin{array}{l}\text { Jarak antara daun pintu } \\
\text { dengan handle pintu }\end{array} \mid$ & 70 & Maks & $\mid \begin{array}{cc}\text { Tebal } & \text { Telapak } \\
\text { Tangan }\end{array}$ & 95 & Pria & 34 & 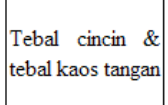 & 20 & 54 & 16 & $\begin{array}{l}\text { Jarak antara daun pintu } \\
\text { dengan handle pintu } \\
\text { aktual sudah lebih baik }\end{array}$ & $\begin{array}{c}\text { Tidak } \\
\text { diperbaiki }\end{array}$ \\
\hline & Diameter handle pintu & 50 & Min & $\begin{array}{c}\text { Diameter } \\
\text { Genggam } \\
\text { (Maksimum) } \\
\end{array}$ & 5 & Wanita & 43 & & & 43 & & Tidak sesuai & Perbaiki \\
\hline & Handle & 950 & Rata-rata & Tinggi Siku & 50 & Wanita & 957 & Tebal sepatu & 30 & 987 & & Tidak sesuai & Perbaiki \\
\hline & $\begin{array}{|lr|}\text { Ruang pada } & \text { saat } \\
\text { menggunakan } & \text { ATM }\end{array}$ & 800 & Maks & Tebal Dada & 95 & Wanita & 278 & Panjang tas & 300 & 578 & & Tidak sesuai & Perbaiki \\
\hline
\end{tabular}

\subsubsection{Fasilitas Penunjang Keamanan Mesin dan Ruangan ATM}

Hal-hal yang perlu diperhatikan oleh nasabah dan pihak bank dalam menunjang keamanan mesin dan ruangan ATM meliputi:

- Pemilihan lokasi mesin ATM sebaiknya tidak di tempat-tempat yang sepi. Hal ini bertujuan agar keselamatan nasabah dan keamanan mesin serta fasilitas yang ada di dalam ruangan ATM dapat diawasi.

- Membuat pengguna ATM tidak mengetahui letak kamera CCTV.

- Pengecekan rutin satu minggu satu kali terhadap fasilitas-fasilitas keamanan yang ada, seperti berfungsinya sensor-sensor yang ada pada mesin ATM, berfungsinya kamera CCTV, dll.

- Pemeriksaan rutin satu minggu satu kali untuk membersihkan kamera pengintai atau alat-alat lainnya yang dipasang oleh pihak tertentu.

- Bank tidak terlalu tergantung kepada pihak kepolisian dalam hal pengamanan mesin ATM.

- Bank bekerjasama dengan aparat kepolisan melakukan patroli untuk mengawasi mesinmesin ATM yang letaknya terpisah dengan kantor.

- Bank menggabungkan mesin ATM menjadi milik bersama agar penjagaannya lebih efisien.

\subsubsection{Fasilitas Penunjang Keselamatan Nasabah Ruangan ATM}

Hal-hal yang perlu diperhatikan oleh pihak bank dalam menunjang keselamatan konsumen dalam bertransaksi menggunakan mesin ATM meliputi:

- Menyediakan petunjuk-petunjuk yang jelas mengenai prosedur-prosedur yang harus dilakukan oleh konsumen apabila terjadi kesalahan dalam menggunakan mesin ATM.

- Kunci slot yang dapat digunakan oleh konsumen dari dalam ruangan ATM pada saat menggunakan mesin ATM.

- Bel yang pengeras suaranya terdapat di luar ruangan yang dapat digunakan oleh nasabah ketika berada dalam keadaan terdesak yang berfungsi untuk meminta bantuan kepada orang lain.

- Pemeriksaan rutin satu minggu satu kali untuk membersihkan ruangan ATM dari brosurbrosur atau kertas yang disebarkan oleh pihak tertentu dengan tujuan menipu nasabah dan kamera pengintai atau alat-alat lainnya yang dipasang oleh pihak tertentu. 
- Bank bekerjasama dengan aparat kepolisan melakukan patroli untuk mengawasi mesinmesin ATM yang letaknya terpisah dengan kantor.

\subsubsection{Tata Letak Ruangan ATM}

Karena adanya keterbatasan luas ruangan ATM, maka alternatif perancangan desain tata letak ruangan ATM juga sangat terbatas. Salah satu yang menjadi penghalang dalam melakukan perancangan desain tata letak ruangan ini adalah kotak perkakas yang berada di dalam ruangan ATM.

Berdasarkan hasil wawancara dengan pihak bank, kotak perkakas tersebut digunakan untuk menyimpan peralatan-peralatan berat yang digunakan untuk perbaikan mesin ATM apabila terjadi kerusakan. Peralatan-peralatan ini juga sebenarnya sering dibawa sendiri oleh teknisi mesin ATM. Sehingga dapat disimpulkan bahwa kotak perkakas tersebut dapat dikeluarkan dari dalam ruangan ATM untuk memberikan efek luas pada tata letak ruangan ATM "BANK A" Setrasari, Bandung.

\subsection{Perancangan Desain Tata Letak Ruangan ATM}

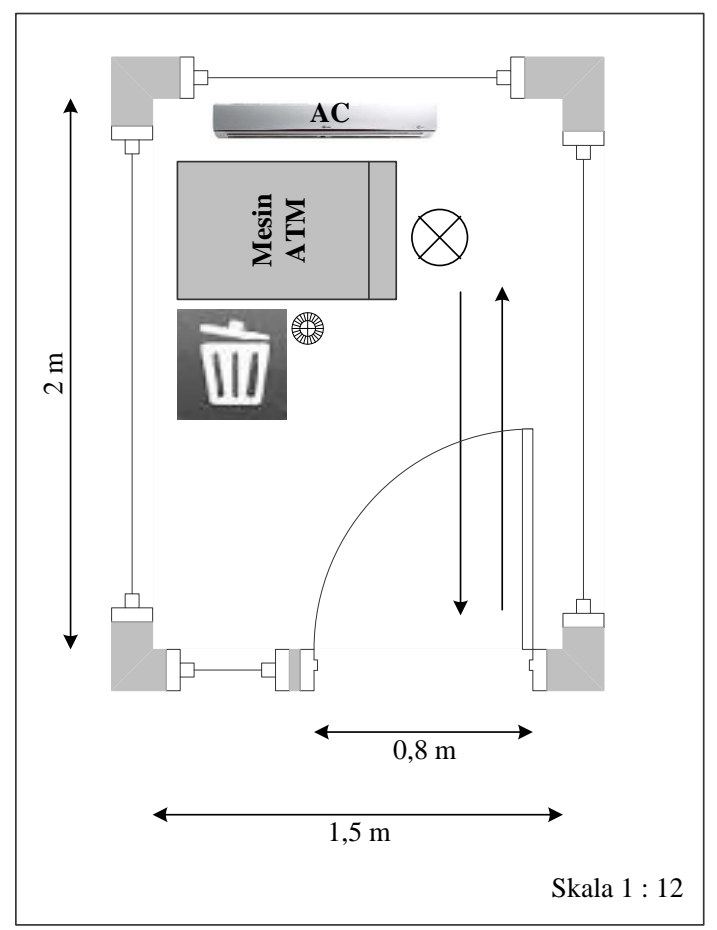

Gambar 12. Perancangan Desain Tata Letak Ruangan ATM

Keterangan:

$\bigotimes \rightarrow$ Tempat nasabah berdiri pada saat menggunakan ATM

IIII $\rightarrow$ Tempat sampah

$\boldsymbol{\forall} \rightarrow$ Jalur masuk - keluar ruangan ATM

$\rightarrow$ Tempat sampah

Kelebihan desain tata letak ruangan ATM yang dirancang bila dibandingkan dengan tata letak ruangan ATM yang sekarang adalah:

- Memberikan efek luas pada ruangan ATM

- Memberikan rasa nyaman kepada pengguna ATM karena tidak perlu memiringkan badan agar pintu dapat terbuka pada saat akan keluar dari dalam ruangan ATM.

- Lebih memberikan rasa aman kepada pengguna ATM karena tidak mudah terlihat pada saat melakukan transaksi. 
Selain itu ditambahkan beberapa perancangan ulang pada ruangan ATM "BANK A" di Setrasari, Bandung yang lain agar dapat menambah kenyamanan dan keamanan bagi para nasabah.

\subsubsection{Sisi Ruangan ATM}

Pada sisi ruangan ATM yang berbatasan dengan ruangan ATM disebelahnya, sebaiknya diberi stiker yang tidak transparan untuk menghindari orang lain melihat kegiatan nasabah pada saat menggunakan ATM.

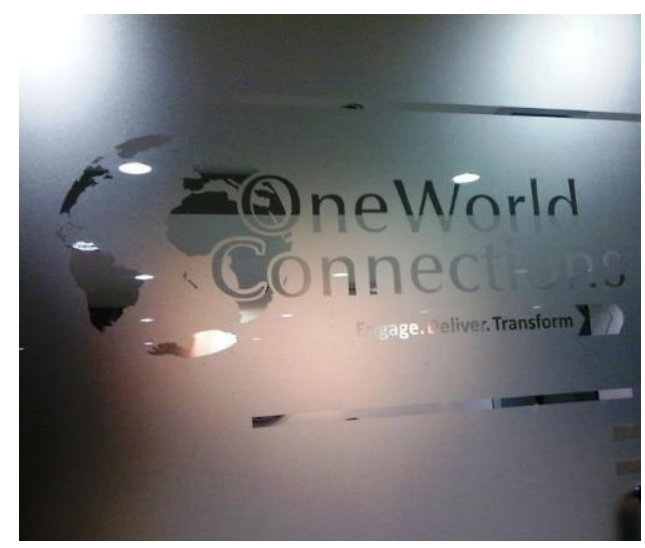

Gambar 13. Contoh Kaca Yang Diberi Stiker

\subsubsection{Penambahan Kunci Slot dan Bel Di Dalam Ruangan ATM}

Penambahan kunci slot dan bel di dalam ruangan ini dimaksudkan agar nasabah dapat merasa lebih aman pada saat bertransaksi menggunakan ATM. Kunci slot berfungsi agar orang lain tidak dapat menerobos masuk ke dalam ruangan ATM bila ATM masih digunakan. Sedangkan bel berfungsi seperti alarm yang menandakan bahaya sehingga ketika ada orang lain yang berusaha menerobos ke dalam ruangan ATM, nasabah dapat menekan bel tersebut sehingga bel tersebut mengeluarkan suara.

\section{Kesimpulan}

Desain ruangan ATM "Bank A" di Setrasari, Bandung saat ini masih terdapat banyak aspek yang belum sesuai dengan ilmu ergonomi. Hal ini dapat disebabkan karena pihak bank kurang memahami pentingnya ilmu ergonomi dan adanya keterbatasan ruangan.

Fasilitas yang disediakan oleh pihak bank dalam menunjang keamanan mesin ATM saat ini sudah cukup memadai. Fasilitas-fasilitas yang terdapat dalam mesin dan ruangan ATM sebenarnya sudah cukup baik seperti berbagai macam sensor yang terdapat dalam mesin ATM dan kamera CCTV yang disediakan oleh pihak bank. Yang perlu ditingkatkan oleh pihak bank adalah melakukan perawatan atau pengecekan rutin terhadap fasilitas-fasilitas tersebut sehingga fasilitas-fasilitas tersebut dapat bekerja secara optimal.

Pada ATM "Bank A" Setrasari, Bandung, posisi ruangan ATM yang lebih rendah dibanding dengan sekitarnya dan dinding yang transparan menyebabkan nasabah seringkali merasa tidak aman dan nyaman pada saat menggunakan ATM. Oleh karena itu tata letak ruangan perlu diubah agar orang lain tidak dapat dengan mudah melihat pengguna ATM yang sedang melakukan transaksi keuangan dan dinding ruangan ATM yang berbatasan dengan ruangan ATM lain sebaiknya diberi stiker yang tidak transparan. Selain itu pintu ATM perlu diberi kunci agar pengguna ATM dapat menggunakannya dari dalam sehingga orang lain tidak dapat masuk pada saat ada yang menggunakan ATM tersebut. 
JOURNAL OF INTEGRATED SYSTEM VOL 1. NO. 1, JUNI 2018: 34-51

\section{Daftar Pustaka}

Bridger, R, S. (2003), Introduction to Ergonomics. ${ }^{\text {nd }}$ Edition. London: Taylor \&Francis.

Corlett, E. N. and Clark, T. S. (1995), The Ergonomics of Workspaces and Machines. A Design Manual. Taylor \& Francis, $2^{\text {nd }}$ erds. USA

Nurmianto, Eko. (2004), Ergonomi: Konsep Dasar dan Aplikasinya. Surabaya: Teknik Industri, ITS.

Pheasant, S., (1991), Ergonomics, Work and Health.

Sutalaksana, Iftikar Z., Ruhana Anggawisastra, John H. TjakraAtmadja, ( 1979), Teknik Tata Cara Kerja, Departemen TI - ITB

Tarwaka, dkk, (2004), Ergonomi Untuk Keselamatan, Kesehatan Kerja dan Produktifitas. Penerbit Uniba Press, Surakarta.

Wignjosoebroto, (2003), Ergonomi, Studi Gerak dan Waktu, Surabaya: PT. Guna Widya.

http://pk.datacrux.org/module.php?module=publisher\&op=viewarticle \&artid=36)

http://id.wikipedia.org/wiki/ATM 